Zespół Szkół Niepublicznych „UNLOCK” we Wrocławiu Nonpublic School Complex "UNLOCK" in Wrocław e-mail: aleksandrapublicewicz93@gmail.com

ANNA OLESZKOWICZ (D) orcid.org/0000-0002-8982-2953

Instytut Psychologii, Uniwersytet Wrocławski Institute of Psychology,University of Wrocław e-mail: anna.oleszkowicz@uwr.edu.pl

\title{
Doświadczenie parentyfikacji a poczucie tożsamości w okresie wczesnej dorosłości
}

\author{
Parentification Experienced in the Past \\ and Sense of Identity in Young Adulthood
}

\begin{abstract}
The main problem of this study is the assessment of the relationship between the level of parentification experienced during adolescence and the intensity of identity-related senses in young adulthood. We took into account three main types of parentification: emotional, instrumental, and perceived unfairness of the role reversal experience and the identity-related senses described by Pilarska (2012, 2016). 181 people aged 19-30 participated in the study, including 95 women. The participants completed the following measures: Filial Responsibility Scale-Adult (past form) (Jurkovic, Thirkield, 1999), the Multidimensional Questionnaire of Identity (Pilarska, 2015), and a demographic survey whose main purpose was to indicate possible risk factors running in the participants' families, such as, disability of family members, chronic somatic or mental illness, addiction, chronic absence, divorce or death of a parent. Results confirmed a higher level of parentification in the risk factor group in comparison with the control group, and the lack of such differences with regard to identity-related senses. The lower level of the sense of one's own boundaries characterized the group with the higher intensity of emotional and instrumental parentification. The lower level of the three identity-related senses (of one's own boundaries, of having inner contents, and of self-worth) was noticeable in the group with a higher score on each parentification dimension. The latter result indicates clear negative effects of parentification associated with its perceived unfairness.
\end{abstract}

Keywords: parentification, role reversal, sense of identity, young adults

Słowa kluczowe: parentyfikacja, odwrócenie ról, poczucie tożsamości osobistej, młodzi dorośli

\section{WPROWADZENIE}

Jakość i przebieg relacji przywiązaniowej z opiekunami ma znaczący wpływ na rozwój dziecka (Bowlby 2007 [1969]). Zniekształcenia tej relacji mogą znacząco odbijać się na zdrowiu psychicznym i relacjach społecznych dziec$\mathrm{ka}, \mathrm{a}$ z czasem nawet osoby dorosłej. Molisa 
Meier i Jean-François Bureau (2018) wyróżnili dwie formy zdezintegrowanego przywiązania, będące relacją odwrócenia ról: przywiązanie kontrolująco-opiekuńcze (controlling/caregiving attachment), które występuje, gdy dziecko rezygnuje z własnych potrzeb, aby odpowiadać na emocjonalne lub fizyczne potrzeby swoich rodziców, i przywiązanie kontrolująco-karzące (controlling/punitive attachment), kiedy dziecko kontroluje interakcje $\mathrm{z}$ rodzicem poprzez bycie wobec nich wrogim. Przykładem przywiązania kontrolująco-opiekuńczego jest zjawisko parentyfikacji, które „obejmuje funkcjonalne lub emocjonalne odwrócenie ról, w którym dziecko poświęca swoje własne potrzeby uwagi, komfortu i bycia prowadzonym w celu dostosowania się do sprawowania opieki nad instrumentalnymi i emocjonalnymi potrzebami rodzica" (Chase, 1999, s. 5). Należy podkreślić, że oczekiwania czy wymagania stawiane dziecku, wynikające $z$ tej specyficznej sytuacji, są nieadekwatne do wieku oraz nadmierne w stosunku do etapu rozwojowego.

Czynnikami ryzyka odwrócenia ról w rodzinie, najczęściej wymienianymi w literaturze przedmiotu, są problemy związane z używaniem substancji psychoaktywnych (Godsall i in., 2004; Pasternak, Schier, 2014), zaburzenia psychiczne rodziców (Van Parys i in., 2015), przewlekłe choroby lub niepełnosprawność członka rodziny (Earley, Cushway, 2002), nieobecność rodzica z powodu pobytu w szpitalu, w więzieniu lub wyjazdów zarobkowych (Sapia-Drewniak, Żarczyńska-Hyla, 2017), niski status socjoekonomiczny (Toro i in., 2019), emigracja rodziny do innego kraju (Hooper, 2007; Titzman, 2012), konflikty małżeńskie i rozwody (Jurkovic, Thirkield, Morell, 2001; Byng-Hall, 2002), samotne rodzicielstwo z powodu śmierci lub rozwodu (Byng-Hall, 2008). Uważa się, że odwrócenie ról może być wielopokoleniowym procesem, w którym deprywacja opieki macierzyńskiej u rodzica lub rodziców może skutkować tendencją do poszukiwania opieki i wsparcia u własnych dzieci (Byng-Hall, 2002; Schier, 2018), a czynników ryzyka poszukuje się także na przykład w niedojrzałości emocjonalnej rodziców (Żarczyńska-Hyla $\mathrm{i}$ in., 2016).

\section{RODZAJE PARENTYFIKACJI}

Badacze parentyfikacji (np. Jurkovic, Thirkield, Morell, 1999; Hooper, Wallace, 2010) rozróżniają jej dwa podstawowe rodzaje: parentyfikację instrumentalną i emocjonalną; wskazują jednocześnie na to, że choć oba najczęściej współwystępują, to mogą, a nawet powinny, być rozpatrywane oddzielnie (Schier, 2018). Parentyfikacja instrumentalna odnosi się do zaspokajania fizycznych potrzeb członków rodziny (przygotowywanie posiłków, załatwianie spraw urzędowych, dbałość o finanse rodziny, wykonywanie czynności pielęgnacyjnych względem członka rodziny itp.) Parentyfikacja emocjonalna natomiast polega na zaspokajaniu przez dziecko emocjonalnych i społecznych potrzeb rodziców, szczególnie tych związanych z poczuciem własnej wartości (Cierpiałkowska, Grzegorzewska, 2016; Schier, 2018). Może to polegać na pełnieniu funkcji przyjaciela, a nawet zastępczego partnera dla rodzica, kiedy na przykład dziecko jest odpowiedzialne za samopoczucie chorego psychicznie rodzica lub ochranianie go przed dezaprobatą innych. Dziecko może też pełnić funkcję rozjemcy między skonfliktowanymi członkami rodziny (Barnett, Parker, 1998; Byng-Hall, 2002).

Badania pokazują, że parentyfikacja emocjonalna wywiera bardziej destrukcyjny wpływ na zdrowie psychiczne osoby jej doświadczającej niż instrumentalna, choć jednocześnie jest znacznie trudniejsza do zaobserwowania (Hooper, 2007; Katz, Petracca, Rabinovitz, 2009; Schier, 2018). Badacze podkreślają też, że znaczący jest sposób, w jaki dziecko postrzega i ocenia sytuację odwrócenia ról - im bardziej uważa ją za krzywdzącą i niesprawiedliwą (czuje się zaniedbane, niezrozumiane i nadmiernie obciążone), tym doświadcza większego poziomu stresu oraz negatywnych konsekwencji dla zdrowia psychicznego i somatycznego (Hooper, Wallace, 2010). Wymieniana jest również parentyfikacja seksualna, którą można potraktować jako formę przemocy seksualnej, w relacji rodzic-dziecko (Fitzgerald i in., 2008; Schier, 2018). 


\section{NEGATYWNE KONSEKWENCJE PARENTYFIKACJI}

W literaturze przedmiotu opisano szereg negatywnych konsekwencji parentyfikacji dla rozwoju psychospołecznego osoby jej doświadczającej w okresie dzieciństwa i/lub młodości. Poczucie niesprawiedliwości związane z parentyfikacją jest znaczącym czynnikiem wyjaśniającym problemy ze zdrowiem psychicznym. U osób $\mathrm{z}$ doświadczeniem emocjonalnej parentyfikacji mogą wystąpić chroniczne stany lęku i depresji w dorosłości (Jacobvitz, Bush, 1996; Hooper, 2007). Zaobserwowano związki między parentyfikacją a zaburzeniami psychosomatycznymi (Schier, 2018) i zaburzeniami odżywiania (Rowa, Kerig, Geller, 2001). Negatywną konsekwencją parentyfikacji są również problemy z przystosowaniem, w tym rozwój zaburzeń internalizacyjnych i eksternalizacyjnych w wieku szkolnym (Carlson, Jacobvitz, Sroufe, 1995; Jacobvitz i in., 2004; Lecompte, Moss, 2014) czy rozwój uzależnień (Hooper i in., 2011). Osoby z doświadczeniem parentyfikacji mogą mieć poczucie nieadekwatności, niższe poczucie własnej wartości i być bardziej skłonne do odczuwania wstydu (Wells, Glicauf-Hughes, Jones, 1999; Castro, Jones, Mirsalimi, 2004).

Mimo tak wielu badań dotyczących negatywnych konsekwencji parentyfikacji nie można jednoznacznie przesądzać o jej wyłącznie szkodliwym wpływie na funkcjonowanie jednostki. Istotną rolę odgrywają także różne zmienne pośredniczące, na przykład rodzaj ryzyka, sposoby zaradcze stosowane przez rodzinę, indywidualna ocena sytuacji (Żarczyńska-Hyla i in., 2016). Jedną z takich zmiennych jest również rezyliencja. Rezyliencja traktowana jest jako umiejętność (zdolność) do pozytywnej adaptacji i efektywnego funkcjonowania w warunkach obciążonych czynnikami ryzyka (np. Egeland, Carlson, Sroufe, 1993; Kwiatkowski, 2017). Umiejętność ta jest możliwa dzięki tak zwanym czynnikom ochronnym, które osłabiają lub wręcz nadają inny sens (np. pozytywny) niekorzystnym warunkom życia. Takich czynników ochronnych poszukuje się w sferze psychospołecznej (np. dobre relacje interpersonalne, wsparcie społeczne, sukcesy edukacyjne, niski poziom przemocy i konfliktów w rodzinie, zdolność do samoregulacji czy wglądu w siebie), jak również w czynnikach biologicznych (np. plastyczność umysłu czy geny) (zob. Curtis, Cicchetti, 2004; Cierpiałkowska, Grzegorzewska, 2016; Kwiatkowski, 2017).

\section{PROBLEMATYKA BADAŃ WLASNYCH}

Z powyższych informacji wynika, że negatywne skutki odwrócenia ról odnoszą się do takich obszarów funkcjonowania, jak: zdrowie psychiczne i fizyczne, przystosowanie społeczne czy rozwój osobowości. Skutki parentyfikacji dotyczą jednak również rozwoju dzieci i młodzieży w kontekście realizacji zadań rozwojowych przypisanych poszczególnym okresom życia (Cierpiałkowska, Grzegorzewska, 2016; Schier, 2018). Młode osoby, które w przeszłości doświadczały odwrócenia ról, mogą mieć trudności w budowaniu relacji romantycznych (Mayseless, Scharf, 2009) i mogą odczuwać niższą satysfakcję ze związków zawieranych w dorosłym życiu (Larson i in., 2000), a nawet wchodzić w relację współuzależnienia (Wells, Jones, 2000). Biorąc pod uwagę zadania rozwojowe charakterystyczne dla okresu adolescencji sformułowane między innymi przez Eriksona, Newmanów, Havighursta (za: Brzezińska, 2000), parentyfikacja może szczególnie niekorzystnie wpływać na: osiągnięcie autonomii w stosunkach z rodzicami, osiąganie bardziej dojrzałych relacji z rówieśnikami, budowanie związków intymnych, przygotowanie się do małżeństwa, rozwój emocjonalny w kierunku większej samoregulacji czy wybór kariery zawodowej.

Jednym z najważniejszych zadań rozwojowych tego okresu jest kształtowanie tożsamości indywidualnej (Erikson, 2004). Do efektywnych poszukiwań tożsamościowych niezbędny jest prawidłowy przebieg procesu separacji - indywiduacji, który ma pomóc jednostce w znalezieniu własnej odrębności i niepowtarzalności. Prawidłowy przebieg tego procesu oznacza 
stopniowe przechodzenie od symbiozy (głównie $\mathrm{z}$ rodzicami i rodziną pochodzenia) do niezależności. Frank Summers (1978) wyróżnił wskaźniki symbiozy, które mogą mieć charakter rozwojowy lub patologiczny: (1) niezróżnicowanie (niemożność rozróżniania własnych przeżyć, emocji, poglądów od tych posiadanych przez innych); (2) intruzyjność behawioralna (przyjmowanie odpowiedzialności za kogoś, przyjmowanie na siebie cudzych problemów); (3) intruzyjność niebehawioralna (silne poczucie, że druga osoba bardzo potrzebuje jej/jego wsparcia); (4) trudności separacyjne - odnośnie do siebie (obawy dotyczące życia w pojedynkę, antycypacja lęków związanych z separacją od innej osoby); (5) trudności separacyjne - odnośnie do innej osoby (nadmierna koncentracja na innych, zamartwianie się, jak tak osoba poradzi sobie $z$ nową sytuacją); (6) dezaprobata dla innych relacji (opór lub dyskomfort w innych relacjach); (7) zależność (silna potrzeba obecności innej osoby lub jej pomocy); (8) wydawanie nakazów (oczekiwanie, że inna osoba powinna zachowywać się w określony sposób) i (9) spełnianie nakazów (duża wrażliwość na oczekiwania innych). Wydaje się, że w przypadku parentyfikacji mogą być one bardziej nasilone i trudne do modyfikacji.

Badania Katarzyny Schier i współpracowników (2018) przeprowadzone na grupie osób dorosłych w wieku od 18 do 63 lat potwierdzają, że doświadczenia parentyfikacji utrudniają proces separacji - indywiduacji. Najsilniejszym predyktorem tych trudności jest spostrzegana niesprawiedliwość, a następnie parentyfikacja emocjonalna (por. Mayseless, Scharf, 2009; Stevens, 2015). W innych badaniach wykazano, że kobiety, które doświadczały zatarcia granic z matką i ojcem, charakteryzowały się mniejszą eksploracją tożsamości w sferze relacji romantycznych i w konsekwencji niższym poziomem zaangażowania $\mathrm{w}$ takie relacje. Zauważono również, że zatarcie granic między ojcem a córką nie sprzyja eksploracji w sferze zawodowej (Fullinwider-Bush, Jacobvitz, 1993). Z kolei Wim Meeusi współpracownicy (2005) testowali hipotezę, że separacja i indywiduacja są procesami paralelnymi (a nie następującymi po sobie), czyli równolegle występują osłabia- nie symbiozy z rodzicami i kształtowanie się tożsamości. W tym celu zbadali związki między wsparciem rodzicielskim, procesami eksploracji i zaangażowania w sferach: relacyjnej i szkolnej/zawodowej oraz przystosowaniem emocjonalnym, w czterech grupach adolescentów w wieku od 12 do 24 lat. Badacze potwierdzili postawioną hipotezę. Wyniki pokazały, że we wczesnej adolescencji lepszym predyktorem dla przystosowania emocjonalnego jest wsparcie rodziców, w późniejszej natomiast adolescencji jego znaczenie słabnie i wzrasta rola procesu zaangażowania. Biorąc pod uwagę wyniki i dyskusję przeprowadzoną przez autorów, można przewidywać, że osoby doświadczające parentyfikacji $\mathrm{w}$ wieku dorastania uzyskują mniej wsparcia od rodziców, które jest ważne dla prawidłowego rozwoju tożsamości, zwłaszcza na początku jej formowania się. Następnie, przez swoje rodzinne uwikłania, prawdopodobnie mają mniejsze szanse na podejmowanie zaangażowania $\mathrm{w}$ różnych sferach, co może skutkować przedłużeniem eksploracji i opóźnionym rozwojem tożsamości. Dodatkowych, bardziej pośrednich przesłanek dla sformułowania pytań badawczych i uzasadnienia hipotez można szukać w badaniach poświęconych uwarunkowaniom kształtowania się tożsamości. Na przykład osoby doświadczające wstydu, winy lub mniejszego poczucia bezpieczeństwa charakteryzują się wyższym nasileniem nieadaptacyjnego procesu eksploracji ruminacyjnej i niższym procesu podejmowania zobowiązania (Brzezińska, Czub, Piotrowski, 2014; Oleszkowicz, Gwiżdż, 2019). W innych badaniach Aleksandra Pilarska i Anna Suchańska (2015) wykazały, że słabsze poczucie wewnętrznej treści, czasowej ciągłości oraz spójności wiąże się z pozabezpiecznym stylem przywiązania (a ten jest bardziej charakterystyczny dla osób doświadczających parentyfikacji).

Biorąc pod uwagę powyższe argumenty, postanowiono zbadać związek między doświadczeniami parentyfikacji w okresie adolescencji a poczuciem tożsamości w okresie wczesnej dorosłości. Ponieważ proces kształtowania się tożsamości ulega obecnie wydłużeniu, chociażby ze względu na uwarunkowania kulturowe, wydaje się ciekawe, do jakiego stopnia może 
on zostać dodatkowo utrudniony przez czynniki indywidualne, $w$ tym przypadku uwarunkowania rodzinne. Współczesne badania poświęcone tożsamości opierają się głównie na dwóch podejściach: rozwojowym - skoncentrowanym na badaniu procesów tożsamościowych, czyli procesów eksploracji i zaangażowania, oraz na podejściu poznawczo-fenomenologicznym. To drugie odwołuje się do kategorii poczucia tożsamości (poczuć tożsamościowych). Choć oba podejścia badają inne aspekty kształtującej się tożsamości, to - jak wykazały Pilarska i Suchańska (2015) - występują istotne współzależności między procesami i poczuciem tożsamości. Ogólna tendencja jest taka, że bardziej zaawansowane procesy tożsamości (np. podejmowanie zobowiązania czy identyfikacja ze zobowiązaniem - por. Luyckx i in., 2008) związane są z relatywnie wyższym poczuciem tożsamości, a mniej zaawansowane procesy (np. eksploracja wszerz lub nieadaptacyjna ruminacja) z niższym poczuciem tożsamości.

Poczucie można rozumieć jako ogólne przeświadczenie na temat własnej osoby i posiadanych właściwości. Ma ono charakter intuicyjny (osoba zdaje sobie sprawę z pewnych faktów i stanów wewnętrznych, choć może mieć problem z ich werbalizacją) i znajduje swoje odzwierciedlenie w świadomości jednostki (Pilarska, 2016). Traktuje się je jako istotną zmienną osobowościową, która stanowi ważny, subiektywny punkt odniesienia (np. przy podejmowaniu różnych decyzji, zobowiązań czy regulacji zachowania). $Z$ tego względu zdecydowano się w badaniach własnych wykorzystać konceptualizację poczuć tożsamościowych zaproponowaną przez Pilarską (2012). Poczucie tożsamości jest specyficznym dla danej osoby sposobem doświadczania siebie, łączącym przeżycie i rozumienie, aspekt emocjonalny i poznawczy (Pilarska, Suchańska, 2015; Pilarska, 2016). Jako takie jest fenomenem wielowymiarowym, który składa się na podmiotowy (subiektywny) aspekt tożsamości i odnosi się do tak zwanych formalnych reprezentacji treści tożsamościowych. Pilarska podkreśla, że wyróżnione poczucia tożsamościowe (poczucie wewnętrznej treści, niepowtarzalności, odrębności i granic, spójności, ciągłości w czasie i własnej wartości) są wymiarami różnic indywidualnych i mogą przybierać różne nasilenia. Zgodnie z intuicjami klinicznymi (Laing, 2004; Johnson, 2012) dopiero harmonijna i pełna struktura poczucia tożsamości ma istotną wartość adaptacyjną i przyczynia się do doświadczania pozytywnych stanów emocjonalnych. Za taką uważa się układ poczuć, z których większość osiąga relatywnie wysokie nasilenie (Pilarska, Suchańska, 2015). Zatem opóźnienie związane z kształtowaniem się tożsamości, również $\mathrm{w}$ jej aspekcie przeżyciowym, jest zjawiskiem niekorzystnym dla psychospołecznego funkcjonowania młodego człowieka.

\section{PYTANIA BADAWCZE I HIPOTEZY}

Biorąc pod uwagę powyższe rozważania, sformułowano następujące pytania badawcze i hipotezy:

1. Czy istnieje różnica $\mathrm{w}$ nasileniu parentyfikacji doświadczanej w okresie adolescencji oraz $\mathrm{w}$ nasileniu poczuć tożsamościowych między młodymi dorosłymi wychowującymi się w rodzinach obciążonych czynnikami ryzyka i bez czynników ryzyka?

H1. W grupie młodych dorosłych wychowujących się w rodzinach obciążonych czynnikami ryzyka nasilenie parentyfikacji doświadczanej w adolescencji jest istotnie większe.

Pytanie o różnicę w nasileniu poczuć tożsamościowych pozostaje otwarte, ponieważ w badaniach własnych uwzględniono jednocześnie bardzo zróżnicowane czynniki ryzyka, które mogły się odnosić zarówno do rodziców, jak i innych członków rodziny.

2. Czy istnieje związek między parentyfikacją doświadczaną w adolescencji a nasileniem poczuć tożsamościowych u młodych dorosłych i na czym on polega?

H2. Istnieje negatywny związek między parentyfikacją a poczuciami tożsamościowymi. Im silniejsze doświadczenie parentyfikacji w okresie adolescencji, 
tym mniejsze nasilenie poczucia tożsamości w poszczególnych wymiarach.

3. Jaki układ rodzajów parentyfikacji jest najmniej korzystny dla nasilenia poczuć tożsamościowych?

H3. Najmniej korzystny układ rodzajów parentyfikacji dla nasilenia poczuć tożsamościowych będzie charakteryzował się co najmniej relatywnie wysokim poziomem parentyfikacji emocjonalnej i spostrzeganej niesprawiedliwości, czyli tych rodzajów parentyfikacji, które uważa się za nieadaptacyjne.

\section{METODA}

\section{Osoby badane}

W badaniach ostatecznie wzięło udział 181 osób w wieku od 19 do 30 lat, w tym 95 kobiet i 86 mężczyzn. Średnia wieku wynosiła ogółem 22.6 roku $(\mathrm{SD}=2.2)$. Wcześniej odrzucono sześć kompletów kwestionariuszy ze względu na braki w ich wypełnieniu. Połowę badań przeprowadzono $\mathrm{w}$ grupach, na terenie wrocławskich uczelni, a połowę w kontakcie indywidualnym (dobór metodą śnieżnej kuli). W badanej grupie wykształcenie na poziomie gimnazjalnym posiadała jedna osoba, 6 osób zakończyło edukację na poziomie zawodowym (3.3\%), 124 osoby (68.5\%) miało wykształcenie średnie, 41 uzyskało wykształcenie licencjackie lub inżynierskie $(22.7 \%)$, a 7 osób (3.9\%) magisterskie. Zdecydowaną większość badanych stanowili studenci wrocławskich uczelni w liczbie 78 (43\%), osób pracujących i uczących się jednocześnie było 60 (33.1\%), natomiast tych, które zakończyły edukację i pracowały - 38 (21\%), a 5 osób (2.8\%) $\mathrm{w}$ momencie badania było na etapie poszukiwania pracy.

W badanej próbie do grupy ryzyka odwrócenia ról zakwalifikowano 107 osób, które zaznaczyły w metryczce jeden lub więcej czynników ryzyka występujących w rodzinie w okresie dorastania (por. „Narzędzia badawcze”), natomiast 74 osoby wychowały się w rodzinie pełnej i nie były obciążone żadnym ze wskazanych w metryczce czynników ryzyka. W grupie osób obciążonych czynnikiem ryzyka było 54 kobiety i 53 mężczyzn, a w grupie wolnej od czynników ryzyka 41 kobiet i 33 mężczyzn. W grupie ryzyka 29 osób zaznaczyło, że w ich rodzinie występował więcej niż jeden czynnik ryzyka. Najczęściej występującymi czynnikami ryzyka była postrzegana „stała nieobecność” rodzica ze względu na charakter wykonywanej pracy lub ze względu na inny rodzaj aktywności (22 osoby) oraz dorastanie w rodzinie niepełnej, zarządzanej przez pojedynczego rodzica, czego doświadczyło 21 osób.

\section{Narzędzia badawcze}

Dane demograficzne, a także informacje o czynnikach ryzyka, zebrano za pomocą metryczki, która odnosiła się do wieku, płci, wykształcenia, miejsca zamieszkania, sytuacji zawodowej, stanu cywilnego osób badanych, liczby rodzeństwa i ich kolejności urodzenia $\mathrm{w}$ rodzinie pochodzenia. Osoby badane mogły zaznaczyć jeden lub więcej z zaproponowanych czynników ryzyka: członek rodziny z niepełnosprawnością fizyczną; członek rodziny z niepełnosprawnością intelektualną, członek rodziny cierpiący na przewlekłą chorobę psychiczną; członek rodziny cierpiący na przewlekłą chorobę fizyczną; członek rodziny wymagający opieki pielęgnacyjnej ze względu na wiek; członek rodziny uzależniony od substancji psychoaktywnych; rodzic bezrobotny; rodzic ,stale nieobecny” ze względu na charakter wykonywanej pracy lub inny rodzaj aktywności; rodzic nieobecny ze względu na pobyt $\mathrm{w}$ więzieniu, rodzina niepełna ze względu na rozwód, separację, śmierć rodzica lub samotne rodzicielstwo. W metryczce wyraźnie zaznaczono, że chodzi o czynniki ryzyka, które obciążały rodzinę $\mathrm{w}$ okresie dorastania osoby badanej.

Do pomiaru nasilenia parentyfikacji i jej rodzajów wykorzystano Skalę Rodzinnej Odpowiedzialności (Filial Responsibility Scale-Adult) autorstwa Gregory'ego Jurkovica i Alison Thirkield (1999). Kwestionariusz składa się z dwóch niezależnych części. Jedna odnosi się do przeszłych doświadczeń rodzinnych (z okresu dorastania), druga dotyczy teraźniejszości. 
W badaniach wykorzystano część „Przeszłość”, w adaptacji własnej. Tłumaczenia pozycji z języka angielskiego dokonała niezależnie jedna $z$ autorek niniejszej pracy oraz filolog angielski. Część „Przeszłość” składa się z trzech podskal zawierających po 10 pozycji. Pozycje oceniane są na 5-stopniowej skali typu Likerta, od ,zdecydowanie się nie zgadzam” do ,zdecydowanie się zgadzam". Podskala parentyfikacja emocjonalna (past expressive caregiving) zawiera pozycje odnoszące się do odgrywania roli osoby odpowiedzialnej za dobrostan członków rodziny (np. „Jeśli jakiś członek mojej rodziny był przygnębiony, przeważnie nie interesowałem się nim"). Podskala parentyfikacja instrumentalna (past instrumental caregiving) zawiera zadania związane z zajmowaniem się gospodarstwem domowym i opieką (np. „Pomagałem mojej rodzinie w zarządzaniu finansami”). Ponieważ trzy pytania $\mathrm{z}$ tego wymiaru odnosiły się do rodzeństwa, odpowiedzi osób badanych, które były jedynakami, zostały uzupełnione średnim wynikiem uzyskanym z odpowiedzi na pozostałe pytania. Ostatnia podskala - spostrzegana niesprawiedliwość (past unfairness) - zawiera pozycje dotyczące subiektywnego poczucia braku równowagi brania i otrzymywania opieki oraz poczucia obciążenia związanego z pomocą rodzinie (np. „W mojej rodzinie często dawałam więcej, niż otrzymywałam"). W każdej podskali osoba mogła uzyskać od 10 do 50 punktów. Współczynnik homogeniczności $\alpha$ Cronbacha, obliczony w badaniach własnych, wynosi odpowiednio: parentyfikacja emocjonalna (0.82), instrumentalna (0.80), spostrzegana niesprawiedliwość (0.90). W kwestionariuszu można obliczyć wynik ogólny (od 30 do 150 punktów). Współczynnik a Cronbacha dla całej skali wynosi (0.92).

Do pomiaru nasilenia poczuć tożsamościowych zastosowano Wielowymiarowy Kwestionariusz Tożsamości autorstwa Pilarskiej (2015) w wersji obejmującej 45 pozycji, odnoszących się do sześciu poczuć tożsamościowych. Pozycje oceniane są na 4-stopniowej skali od „zdecydowanie nie / nigdy”, do ,zdecydowanie tak / zawsze". Zgodnie z koncepcją Pilarskiej (2012;
2016) poczucie posiadania wewnętrznej treści to sposób doświadczenia siebie jako osoby mającej wgląd we własne myśli, uczucia i intencje (np. ,Wiem dokładnie, co czuję i czego chcę" 5 pozycji). Poczucie niepowtarzalności odnosi się do przeżywania siebie jako osoby specyficznej, jedynej w swoim rodzaju (np. „Mam nieodparte wrażenie, że jestem kimś wyjątkowym i oryginalnym na tle świata ludzi” - 9 pozycji). Podskala poczucia odrębności i granic doświadczania siebie jako osoby odrębnej od innych ludzi obejmuje 7 pozycji (np. „Łatwo przyjmuję nastroje i uczucia innych ludzi"). Odczuwanie siebie jako osoby zintegrowanej zostało nazwane poczuciem spójności (np. „Mam poczucie wewnętrznej harmonii i ładu" - 10 pozycji). Poczucie ciągłości jest rodzajem doświadczenia stałości siebie samego mimo zachodzących zmian (np. „Ciągłe zmiany w moim charakterze sprawiają, że nie wiem, kim jestem" - 8 pozycji). Ostatnim z poczuć tożsamościowych jest poczucie własnej wartości, czyli sposób przeżywania siebie jako jednostki godnej szacunku i wartościowej (np. „Wiem, że osiągnięcie sukcesu, szacunku czy miłości jest dla mnie dostępne" 6 pozycji). Wskaźnikiem nasilenia poczucia tożsamości w danym wymiarze jest średnia liczba punktów mieszcząca się w przedziale $0-3$. Im wyższy wynik, tym większe nasilenie poczucia tożsamości w danym wymiarze. Istnieje możliwość obliczenia ogólnego poczucia tożsamości, jednak w tym badaniu z takiej możliwości nie skorzystano. Współczynniki homogeniczności $\alpha$ Cronbacha dla podskal osiągały wartości z przedziału $\alpha=0.60-0.81$, ze średnią $\alpha=$ 0.71 (Pilarska, 2015). W badaniach własnych najniższy współczynnik $\alpha$ Cronbacha uzyskała podskala Poczucie odrębności (0.62), a najwyższy Poczucie niepowtarzalności (0.85); średni wynik wyniósł $\alpha=0.76$.

\section{WYNIKI}

Przed przystąpieniem do właściwych analiz statystycznych zostały obliczone statystyki opisowe dla badanych zmiennych. 
Tabela 1. Statystyki opisowe dla poczuć tożsamościowych i rodzajów parentyfikacji

\begin{tabular}{|l|c|c|c|c|}
\hline \multicolumn{1}{|c|}{ Zmienne } & $\boldsymbol{M}$ & $\boldsymbol{S D}$ & Skośność & Kurtoza \\
\hline PWT & 2.08 & .51 & -.61 & -.33 \\
\hline PN & 1.82 & .53 & -.41 & .41 \\
\hline PO & 1.54 & .46 & .14 & .08 \\
\hline PS & 1.90 & .50 & -.51 & -.01 \\
\hline PC & 1.85 & .49 & -.29 & .40 \\
\hline PWW & 1.99 & .55 & .58 & -.10 \\
\hline PARI & 23.00 & 7.52 & .17 & -.61 \\
\hline PARE & 27.93 & 8.12 & .26 & -.36 \\
\hline NIESP & 24.51 & 9.36 & .43 & -.58 \\
\hline PARENT & 75.45 & 20.56 & .32 & -.21 \\
\hline
\end{tabular}

Oznaczenia: PWT - poczucie posiadania wewnętrznej treści, PN - poczucie niepowtarzalności, PO - poczucie odrębności i granic, PS - poczucie spójności, PC - poczucie ciągłości, PWW - poczucie własnej wartości, PARI - parentyfikacja instrumentalna, PARE - parentyfikacja emocjonalna, NIESP - spostrzegana niesprawiedliwość, PARENT - parentyfikacja ogólna

Jak wynika z tabeli 1, na podstawie wskaźników skośności i kurtozy można przyjąć, że zmienne charakteryzowały się rozkładem normalnym i do dalszych analiz będą wykorzystywane testy parametryczne. Średnie wyniki w rodzajach parentyfikacji i w parentyfikacji ogólnej usytuowały się poniżej środka skal wyników surowych. Kwestionariusz nie posiada norm, które mówiłyby, od jakiego wyniku mamy do czynienia z parentyfikacją. Z kolei średnie wyniki odnoszące się do poczuć tożsamościowych usytuowały się w środku skali wyników surowych lub nieco wyżej.
W celu uzyskania odpowiedzi na pytanie 1 przeprowadzono badanie różnic w nasileniu poczuć tożsamościowych i nasileniu parentyfikacji między grupami obciążonymi (CR) i nieobciążonymi czynnikami ryzyka (brak CR).

Na podstawie danych zawartych $w$ tabeli 2 można stwierdzić, że wystąpiły różnice istotne statystycznie w nasileniu wszystkich rodzajów parentyfikacji oraz w parentyfikacji ogólnej. Nasilenie parentyfikacji doświadczanej w okresie adolescencji było silniejsze w grupie osób, które dorastały w rodzinach obciążonych czynnikami ryzyka. Tym samym została potwierdzona

Tabela 2. Różnice w nasileniu badanych zmiennych między grupami obciążonymi i nieobciążonymi czynnikami ryzyka, test $t$ Studenta dla grup niezależnych

\begin{tabular}{|l|c|c|c|c|c|c|c|}
\hline Zmienne & $\begin{array}{c}\text { Średnia } \\
\text { (brak CR) }\end{array}$ & $\begin{array}{c}\text { Średnia } \\
\text { (CR) }\end{array}$ & T & df & $\mathbf{p}$ & $\begin{array}{c}\mathbf{F} \\
\text { wariancje }\end{array}$ & P \\
\hline PWT & 2.08 & 2.08 & -.07 & 179 & .94 & 1.02 & .93 \\
\hline PN & 1.84 & 1.81 & .37 & 179 & .71 & 1.02 & .92 \\
\hline PO & 1.57 & 1.52 & .73 & 179 & .46 & 1.09 & .69 \\
\hline PS & 1.91 & 1.89 & .25 & 179 & .80 & 1.01 & .92 \\
\hline PC & 1.85 & 1.85 & -.03 & 179 & .97 & 1.15 & .51 \\
\hline PWW & 2.03 & 1.96 & .70 & 179 & .48 & 1.08 & .71 \\
\hline PARI & $21.28^{*}$ & 24.20 & -2.60 & 179 & .01 & 1.17 & .47 \\
\hline PARE & $24.49^{*}$ & 30.31 & -5.06 & 179 & $>.000$ & 1.42 & .11 \\
\hline NIESP & $21.81^{*}$ & 26.39 & -3.32 & 179 & .001 & 1.01 & .96 \\
\hline PARENT & $6.58^{*}$ & 80.91 & -4.51 & 179 & $>.000$ & 1.03 & .89 \\
\hline
\end{tabular}

$\mathrm{N} 1(\mathrm{CR})=107 ; \mathrm{N} 2($ brak CR $)=74 ; * \mathrm{p}<.05$ 
Tabela 3. Związek między parentyfikacja i jej rodzajami a poczuciami tożsamościowymi ( $r$ Pearsona, $\mathrm{N}=181$ )

\begin{tabular}{|l|c|c|c|c|c|c|}
\hline Zmienne & PWT & PN & PO & PS & PC & PWW \\
\hline PARENT & $-.18^{*}$ & -.06 & $-.29^{*}$ & -.12 & -.14 & $-.25^{*}$ \\
\hline PARI & -.10 & -.07 & $-.24^{*}$ & -.00 & -.10 & -.11 \\
\hline PARE & -.09 & -.00 & $-.26^{*}$ & -.03 & -.02 & -.11 \\
\hline NIESP & $-.23^{*}$ & -.07 & -.08 & $-.24^{*}$ & $-.22^{*}$ & $-.35^{*}$ \\
\hline
\end{tabular}

Poziom istotności * $\mathrm{p}<.05$

hipoteza H1. Badane grupy nie różniły się pod względem nasilenia poczuć tożsamościowych. Kolejne pytanie badawcze dotyczyło związku między parentyfikacją a poczuciami tożsamościowymi. Uzyskane korelacje zostały przedstawione w tabeli 3.

Dane zawarte w tabeli 3 dowodzą, że jedynym poczuciem tożsamościowym niezwiązanym z wcześniej doświadczaną parentyfikacją było poczucie niepowtarzalności. Pozostałe poczucia tożsamościowe weszły w związki z parentyfikacją ogólną lub jej rodzajami, zgodnie z postawioną hipotezą $\mathrm{H} 2$, czyli im większe nasilenie doświadczanej w adolescencji parentyfikacji, tym mniejsze nasilenie poczuć tożsamościowych. Poziom uzyskanych korelacji był niski. Najwięcej relacji między parentyfikacją a jej rodzajami wystąpiło w przypadku poczucia odrębności i granic. Tutaj obok parentyfikacji ogólnej istotne znaczenie miała parentyfikacja emocjonalna (zaspokajanie potrzeb rodzica) i parentyfikacja instrumentalna (podejmowanie obowiązków za rodzica). Badania ujawniły również negatywny związek spostrzeganej niesprawiedliwości z czterema spośród sześciu poczuć tożsamościowych.
W celu odpowiedzi na pytanie 3 przeprowadzono analizę skupień, metodą grupowania k-średnich, dla trzech rodzajów parentyfikacji. Testowano 2, 3 i 4 skupienia w celu uzyskania wyraźnie odrębnych układów. Optymalne okazały się trzy skupienia, które można opisać w następujący sposób. Skupienie $1(\mathrm{~N}=73)$ objęło osoby o relatywnie niskim poziomie wszystkich rodzajów parentyfikacji (35 osób pochodziło z rodzin z występującymi czynnikami ryzyka, liczba kobiet wynosiła 39, liczba osób posiadających rodzeństwo 56). Skupienie $2(\mathrm{~N}=47)$ zgrupowało osoby o relatywnie wysokich wskaźnikach w parentyfikacji emocjonalnej i instrumentalnej oraz o niskim poczuciu niesprawiedliwości (27 osób pochodziło z rodzin z występującymi czynnikami ryzyka, liczba kobiet wynosiła 27, a osób posiadających rodzeństwo 39). To skupienie nazwano obciążającym. Skupienie $3(\mathrm{~N}=61)$ zgrupowało osoby o relatywnie najwyższych wskaźnikach parentyfikacji (45 osób pochodziło z rodzin obciążonych czynnikami ryzyka, liczba kobiet - 29, liczba osób posiadających rodzeństwo 47). To skupienie nazwano zaburzającym. Wyniki analizy skupień zostały zawarte w tabeli 4.

Tabela 4. Średnie wyniki poszczególnych rodzajów parentyfikacji w trzech skupieniach

\begin{tabular}{|l|c|c|c|}
\hline Zmienne & $\begin{array}{c}\text { 1 SKUPIENIE } \\
\text { niskie } \\
\mathbf{N = 7 3}\end{array}$ & $\begin{array}{c}\text { 2 SKUPIENIE } \\
\text { obciążające } \\
\mathbf{N}=\mathbf{4 7}^{-}\end{array}$ & $\begin{array}{c}\text { 3 SKUPIENIE } \\
\text { zaburzające } \\
\mathbf{N}=\mathbf{6 1}\end{array}$ \\
\hline PARI & $16.49^{\mathrm{a}}$ & $26.65^{\mathrm{b}}$ & $27.98^{\mathrm{b}}$ \\
\hline PARE & $20.71^{\mathrm{a}}$ & $30.53^{\mathrm{b}}$ & $34.57^{\mathrm{c}}$ \\
\hline NIESP & $19.56^{\mathrm{a}}$ & $18.87^{\mathrm{a}}$ & $34.80^{\mathrm{b}}$ \\
\hline
\end{tabular}

Różnice istotne statystycznie $(\mathrm{p}<.05)$ w wierszach oznaczone literami. Ta sama litera oznacza brak różnicy. 


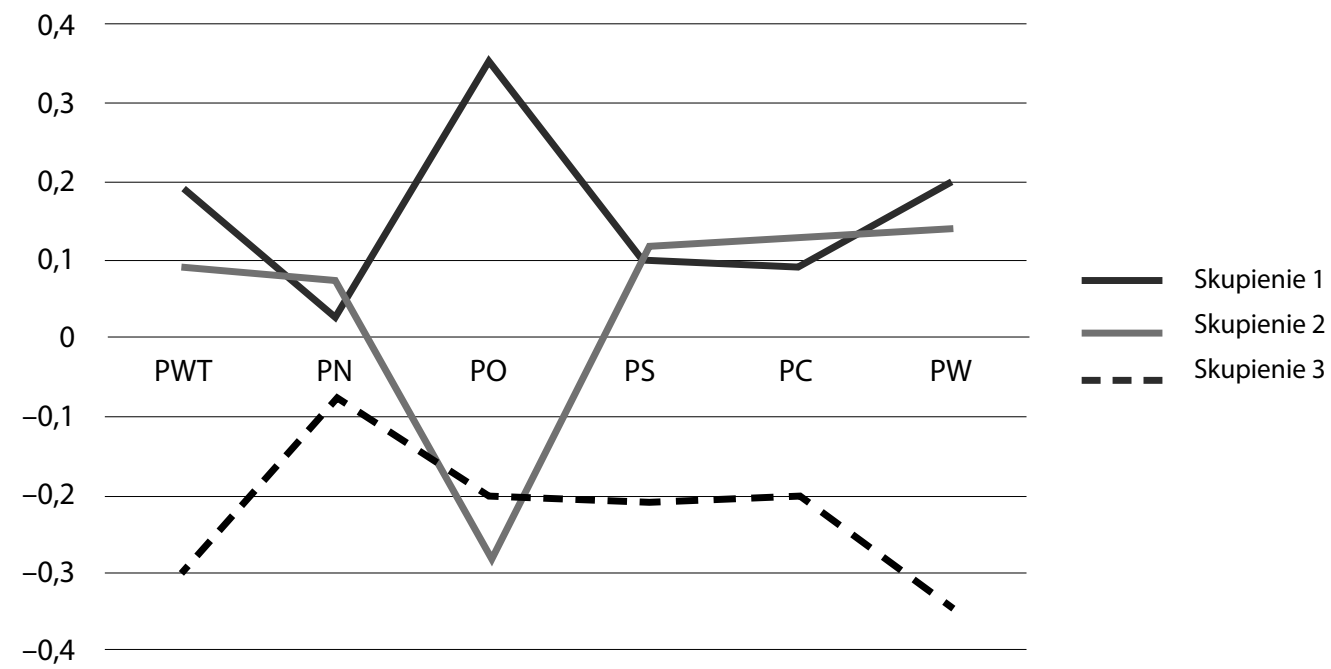

Rysunek 1. Nasilenie poczuć tożsamościowych w wyodrębnionych skupieniach (wyniki wystandaryzowane)

Następnie porównano skupienia ze względu na poziom nasilenia poszczególnych poczuć tożsamościowych. Analizę przeprowadzono za pomocą jednoczynnikowego testu ANOVA. W przypadku wystąpienia efektu głównego zastosowano porównania post hoc za pomocą testu Tukeya dla grup nierównolicznych. Układ poszczególnych poczuć tożsamościowych obrazuje rysunek 1 .

Efekt główny wystąpił w przypadku trzech poczuć tożsamościowych. W nasileniu poczucia posiadania wewnętrznej treści (PWT): $\mathrm{F}=4.30$; $\mathrm{df}=2 ; \mathrm{p}<.01 ;$ eta $^{2}=.05 ; \mathrm{w}$ poczuciu odrębności (PO): $\mathrm{F}=8.35 ; \mathrm{df}=2 ; \mathrm{p}<.0001$; $\mathrm{eta}^{2}=$ .09 oraz w poczuciu własnej wartości $(\mathrm{PW})$ : $\mathrm{F}=6.12 ; \mathrm{df}=2 ; \mathrm{p}<.002 ; \mathrm{eta}^{2}=.06$, czyli w tych poczuciach, w których stwierdzono współzależność z parentyfikacją ogólną rozumianą jako suma wszystkich rodzajów parentyfikacji (por. tabela 3). Procent wariancji wyjaśnianej w nasileniu wskazanych poczuć wyniósł od 5\% do 9\%. Najbardziej niekorzystny dla rozwoju poczuć tożsamościowych był układ parentyfikacji opisany w skupieniu 3 (zaburzającym), co jest zgodne z hipotezą H3. W skupieniu tym w sposób istotny statystycznie, w stosunku do dwóch pozostałych, na najniższym poziomie wystąpiły poczucia tożsamościowe związane z posiadaniem wewnętrznej treści oraz poczuciem własnej wartości. Również na znacznie niższym poziomie (w stosunku do skupienia 1) było poczucie odrębności. Skupienie 2 (obciążające) okazało się z kolei bardzo niekorzystne dla kształtującego się poczucia odrębności jednostki. W tym zakresie różniło się na niekorzyść od skupienia 1 i było podobne do skupienia 3 (zaburzającego).

\section{DYSKUSJA}

Na początek odniesiemy się do wyników porównania nasilenia parentyfikacji i poczuć tożsamościowych w dwóch grupach: w grupie ryzyka i w grupie kontrolnej. Zgodnie $\mathrm{z}$ dość dobrze udokumentowaną wiedzą na temat czynników ryzyka sprzyjającym parentyfikacji (por. „Wprowadzenie”) nasze badania pokazały, że istotnie silniejsze doświadczenia związane z parentyfikacją wystąpiły u osób wychowujących się $w$ rodzinach obciążonych ryzykiem. Uwzględnione w badaniach czynniki ryzyka były wskazywane przez osobę badaną. Jednocześnie były to czynniki o charakterze obiektywnym, czyli możliwe do zaobserwowania 
przez innych (np. choroby, uzależnienia, rozwód czy długa nieobecność). Czynniki tego typu mogą silnie i bezpośrednio oddziaływać na sytuację dziecka w rodzinie i odgrywaną przez niego rolę. Jednocześnie nie stwierdzono różnic między badanymi grupami w zakresie nasilenia poczuć tożsamościowych. Oznacza to, że sam fakt występowania w rodzinie adolescenta czynników ryzyka nie musi przynosić negatywnych skutków w postaci opóźnienia procesu kształtowania się tożsamości w okresie wczesnej dorosłości. Potwierdzają to niektóre wyniki badań uzyskiwane w grupach bardziej jednorodnych.

Na przykład Ewa Stępień (1991) porównywała adolescentów $\mathrm{z}$ rodzin $\mathrm{z}$ chorobą alkoholową i z grupy kontrolnej pod względem realizacji zadań rozwojowych, takich jak: samodzielne radzenie sobie z własnymi sprawami, posiadanie grona bliskich przyjaciól, planowanie dorosłego życia, akceptacja wyglądu i orientacja w regułach życia społecznego. Istotne różnice na niekorzyść dzieci z rodzin alkoholików dotyczyły tylko samodzielności i orientacji w regułach życia społecznego. Z kolei z badań Iwony Grzegorzewskiej (2011) wynika, że adolescenci z rodzin niepijących, leczących się alkoholików realizują zadania rozwojowe na podobnym poziomie jak dzieci z rodzin bez problemu alkoholowego oraz z rodzin pijących alkoholików. Oznacza to, że pomiędzy czynnikami ryzyka występującymi w rodzinie pochodzenia a negatywnymi skutkami dla rozwoju (w tym rozwoju tożsamości) pośredniczą różne zmienne, które modyfikują niekorzystne uwarunkowania. Jedną z nich może być nasilenie parentyfikacji.

Porównanie grup wskazuje na relatywnie wyższe nasilenie parentyfikacji w grupie obciążonej czynnikami ryzyka, a to oznacza, że $\mathrm{w}$ grupie kontrolnej takie zjawisko również występuje. Wynik ten można wyjaśnić na dwa sposoby. Po pierwsze, w grupie kontrolnej mogły wystapić inne obiektywne czynnikami ryzyka, nieujęte w metryczce, na przykład niski status ekonomiczny (McMahon, Luthar, 2007; Jelastopulu, Tzoumerka, 2013). Po drugie, co jest bardziej prawdopodobne, mogły wystąpić mniej oczywiste i trudniejsze do zaobserwowania czynniki ryzyka wynikające ze sposo- bu funkcjonowania i odnoszenia się do siebie członków rodziny, które również przyczyniały się do doświadczania parentyfikacji, na przykład pozabezpieczny styl przywiązania (Macfie, Brumariu, Lyons-Ruth, 2015), depresyjność i rygoryzm rodziców (Żarczyńska-Hyla i in., 2016), bezradność matek (Lecompte, Moss, 2014), konflikty w rodzinie (Peris i in., 2008) czy brak elastycznych, jasno wyznaczonych granic pokoleniowych (Byng-Hall, 2002).

Analiza skupień pozwoliła na wyodrębnienie trzech grup osób badanych różniących się nie tylko nasileniem, ale i układem rodzajów parentyfikacji. W skupieniu 1 znalazło się nieco więcej osób z grupy bez czynników ryzy$\mathrm{ka}$, natomiast $\mathrm{w}$ skupieniu 3 - zaburzającym znacznie więcej osób z grupy ryzyka. Wynik ten wskazuje na to, że sam fakt wystąpienia tak zwanych obiektywnych czynników ryzyka nie musi wywoływać u badanych podobnych doświadczeń związanych z parentyfikacją. Czynnikiem pośredniczącym w tej relacji może być wspomniana we wprowadzeniu rezyliencja i związane z nią zasoby ochronne. Badania pokazują ponadto, że nasilenie parentyfikacji w pewnym stopniu zależy od cech, którymi charakteryzują się sami rodzice. Im większe ciepło i zapobiegliwość rodziców, tym słabsze: parentyfikacja instrumentalna, emocjonalna i poczucie krzywdy. Z kolei silniejsza parentyfikacja wiąże się z depresyjnością rodziców i apodyktycznością (Żarczyńska-Hyla i in., 2016).

Poszukiwanie związków między parentyfikacją a nasileniem poczuć tożsamościowych ujawniło dwie interesujące prawidłowości. Po pierwsze, osoby doświadczające istotnie wyższej parentyfikacji na wymiarze instrumentalnym i emocjonalnym oraz znacznie niższej na wymiarze spostrzeganej niesprawiedliwości (tzw. skupienie obciążające) mogą mieć przede wszystkim problem z wypracowaniem poczucia odrębności czy niezależności. Wynik ten jest zgodny z badaniami uzyskiwanymi przez na przyład Olfrę Mayseless i Miri Scharf (2009) czy Katarzynę Schier (2016) oraz z wiedzą na temat prawidłowości przebiegu procesu separacji-indywiduacji. Uzyskana zależność nie przesądza o sposobie funkcjonowania jednostki. Niższe poczucie odrębności nie musi dawać rezultatów 
w postaci dyskomfortu czy poczucia ograniczenia, choć $\mathrm{z}$ punktu widzenia wiedzy o rozwoju człowieka jest to sytuacja mniej korzystna dla formującej się tożsamości. U wielu osób (o ile sprzyja temu klimat rodzinny i bliskość więzi) mniejsze poczucie odrębności może występować w przypadku tożsamości lustrzanej czy w normatywnym stylu tożsamości (Oleszkowicz, Senejko, 2013).

Negatywne skutki parentyfikacji występują wtedy, gdy obok parentyfikacji emocjonalnej $\mathrm{i}$ instrumentalnej relatywnie wysokie nasilenie dotyczy również poczucia niesprawiedliwości (skupienie zaburzające). U osób z tego skupienia stwierdzono istotnie niższy poziom poczucia posiadania wewnętrznej treści i poczucia własnej wartości w porównaniu z pozostałymi. Wynik ten jest zgodny $\mathrm{z}$ wiedzą na temat szkodliwych skutków postrzegania sytuacji odwrócenia ról jako niesprawiedliwej i krzywdzącej (Hooper, Wallace, 2010; Jankowski i in., 2013). Poczucie wewnętrznej treści odnosi się do posiadania własnych myśli, przekonań, motywacji czy uczuć. Słabsze przekonanie o tym, że treść życia wewnętrznego jest osobiście zaakceptowana i włączona w sposób myślenia o sobie i świecie, może doprowadzać do inercji i chaosu decyzyjnego w codziennym funkcjonowaniu. Podobnie jest w przypadku mniejszego poczucia własnej wartości. Odnosi się ono do przekonania o byciu osobą ważną, zasługującą na zauważanie i szacunek. Ponadto wiąże się z przekonaniem o możliwości realizacji własnych zamierzeń. Niższe poczucie własnej wartości sprzyja bezradności, wycofywaniu się z podejmowania ważnych decyzji, niepewności i niewiary w sukces (Pilarska, Suchańska, 2015; Pilarska, 2016).
Jednostka narażona jest zatem na długotrwały dyskomfort i być może utratę istotnych dla siebie życiowych szans. Tego typu negatywne konsekwencje mogą być szczególnie dotkliwe dla młodych dorosłych, od których oczekuje się podejmowania samodzielnych i odpowiedzialnych decyzji.

Nie potwierdziła się hipoteza o negatywnym związku parentyfikacji z poczuciem niepowtarzalności. Wyniki ujawniły brak takiej zależności. Nie można wykluczyć, że część osób badanych postrzega swoją sytuację rodzinną i odgrywaną w niej rolę jako nietypową, niepowtarzającą się u innych. Tym samym będzie budować poczucie niepowtarzalności na swoich negatywnych doświadczeniach. Z kolei inne osoby mogą odczuwać swoją niepowtarzalność jako znacznie słabszą ze względu na pojawiające się problemy separacyjne.

Na zakończenie należy wskazać na pewne ograniczenia przeprowadzonych badań. Pierwszym z nich była badana próba, która obejmowała głównie młodych dorosłych pozostających w procesie edukacji, co ograniczało możliwość pogłębionej syntezy wyników. Drugie utrudnienie polegało na braku szczegółowych informacji na temat wziętych pod uwagę czynników ryzyka, na przykład w jakim stopniu dotyczyły one rodziców, a w jakim innych członków rodziny, lub kiedy wystąpiły po raz pierwszy. Kolejnym problemem był retrospektywny charakter badań, który wiązał się z pewną deformacją oceny sytuacji rodzinnej w poprzedzającym prace badawcze okresie rozwojowym. Bardziej korzystne byłyby badania podłużne, które pozwoliłyby na lepsze rozpoznanie psychologicznych mechanizmów leżących u podstaw analizowanych związków.

\section{BIBLIOGRAFIA}

Barnett B., Parker G. (1998), The parentified child: Early competence or childhood deprivation? Child and Adolescent Mental Health, 3(4), 146-155.

Bowlby J. (2007 [1969]), Przywiazanie. Warszawa: Wydawnictwo Naukowe PWN.

Brzezińska A. (2000), Społeczna psychologia rozwoju, thum. M. Polaszewska-Nicke. Warszawa: Wydawnictwo Naukowe PWN.

Brzezińska A., Czub T., Piotrowski K. (2014), Statusy tożsamości a style tożsamości i funkcjonowanie emocjonalne uczniów szkół zawodowych. Psychologia Rozwojowa, 19(4), 51-71. 
Byng-Hall J. (2002), Relieving parentified children's burdens in families with insecure attachment pattern. Family Process, 41(3), 375-388.

Byng-Hall J. (2008), The significance of children fulfilling parental roles: Implications for family therapy. Journal of Family Therapy, 30, 147-162.

Carlson E.A., Jacobvitz D., Sroufe L.A. (1995), A developmental investigation of inattentiveness and hyperactivity. Child Development, 66(1), 37-54.

Castro D.M., Jones R.A., Mirsalimi H. (2004), Parentification and impostor phenomenon: An empirical investigation. American Journal of Family Therapy, 32(3), 205-216.

Chase N.D. (1999), Parentification: An overview of theory, research, and societal issues. W: N. Chase (red.), Burdened children: Theory, research, and treatment of parentification, 3-34, Thousand Oaks: SAGE Publishing.

Cierpiałkowska L., Grzegorzewska I. (2016), Dzieci alkoholików w perspektywie rozwojowej i klinicznej. Poznań: Wydawnictwo Naukowe PWN.

Curtis W.J., Cicchetti D. (2004), Rozwijanie badań nad rezyliencją w XXI wieku: Rozważania teoretyczne i metodologiczne w ocenie biologicznych składników rezyliencji. Audiofonologia, 4, 65-91.

Earley L., Cushway D. (2002), The parentified child. Clinical Child Psychology and Psychiatry, 7(2), 163-178.

Egeland B., Carlson E., Sroufe A.L. (1993), Resillience as a process. Development and Psychology, 5, 517-528.

Erikson E.H. (2004), Dzieciństwo i społeczeństwo. Poznań: Dom Wydawniczy Rebis.

Fitzgerald M.M., Schneider R.A., Salstorm S., Zinzow H.M., Jackson J., Fossel R.V. (2008), Child sexual abuse, early family risk, and childhood parentification: Pathways to current psychosocial adjustment. Journal of Family Psychology, 22(2), 320-324.

Fullinwider-Bush N., Jacobvitz D. (1993), The transition to young adulthood: Generational boundary dissolution and female identity development. Family Process, 32(1), 87-103.

Godsall R.E., Jurkovic G.J., Emshoff J., Anderson L., Stanwyck D. (2004), Why some kids do well in bad situations: Relations of parental alcohol misuse nad parentification to children's self-concept. Substance Use \& Misuse, 39(5), 789-809.

Hooper L.M. (2007), The application of attachment theory and family systems theory to the phenomena of parentification. The Family Journal: Counselling and Therapy for Couples and Families, 15(3), 217-223.

Hooper L.M., DeCoster J., White N., Voltz M. L. (2011), Characterizing the magnitude of the relation between self-reported childhood parentification and adult psychopathology: A meta-analysis. Journal of Clinical Psychology, 67(10), 1028-1043.

Hooper L.M., Wallace S.A. (2010), Evaluating the Parentification Questionnaire: Psychometric properties and psychopathology correlates. Contemporary Family Therapy, 32(1), 52-68.

Jacobvitz D.B., Bush N.F. (1996), Reconstructions of family relationships: Parent-child alliances, personal distress, and self-esteem. Developmental Psychology, 32(4), 732.

Jacobvitz D., Hazen N., Curran M., Hitchens K. (2004), Observations of early triadic family interactions: Boundary disturbances in the family predict symptoms of depression, anxiety, and attention-deficit/hyperactivity disorder in middle childhood. Development and Psychopathology, 16(3), 577-592.

Jankowski P.J., Hooper L.M., Sandage S.J., Hannah N.J. (2013), Parentification and mental health symptoms: Mediator effects of perceived unfairness and differentiation of self. Journal of Family Therapy, 35(1), $43-65$.

Jelastopulu E., Tzoumerka K.A. (2013), The effects of economic crisis on the phenomenon of parentification. Universal Journal of Psychology, 1(3), 145-151.

Johnson S.M. (2012), Style charakteru, tłum. B. Mizia. Poznań: Zysk i Ska Wydawnictwo.

Jurkovic G.J., Thirkield A., Morrell R. (2001), Parentification of adult children of divorce: A multidimensional analysis. Journal of Youth and Adolescence, 30(2), 245-257.

Jurkovic G.J., Thirkield A. (1999), Filial Responsibility Scale-Adult (FRS-A). Unpublished document, Department of Psychology, Georgia State University, Atlanta, GA.

Kwiatkowski P. (2017), Biologiczny kontekst rezyliencji - implikacje dla psychoprofilaktyki. Serwis informacyjny UZALEŻNIENIA, 4(80), 16-20.

Laing R.D. (2004), Podzielone ,ja”, tłum. M. Karpiński. Poznań: Rebis. 
Larson J., Peterson D., Heath V.A., Birch P. (2000), The relationship between perceived dysfunctional family-oforgin rulet and intimacy in young adult dating relationships. Journal of Sex \& Marital Therapy, 26, 161-175.

Lecompte V., Moss E. (2014), Disorganized and controlling patterns of attachment, role reversal and caregiving helplessness: Links to adolescent externalizing problems. American Journal of Orthopsychiatry, 84(5), 581-589.

Luyckx K., Schwartz S.J., Berzonsky M., Soenens B., Vansteenkiste M., Smits I., Goossens L. (2008), Capturing ruminative exploration: Extending the four-dimensional model of identity formation in late adolescence. Journal of Research in Personality, 42, 58-82.

Macfie J., Brumariu L.E., Lyons-Ruth K. (2015), Parent-child role confusion: A critical review of an emerging concept. Developmental Review, 36, 34-57.

McMahon T.J., Luthar S.S. (2007), Defining characteristics and potential consequences of caretaking burden among children living in urban poverty. American Journal of Orthopsychiatry, 77(2), 267-281.

Mayseless O., Scharf M. (2009), Too close to comfort: Inadequate boundaries with parents and individuation in late adolescent girls. American Journal of Orthopsychiatry, 79(2), 191-202.

Meeus W., Iedema J., Maassen G., Engels R. (2005), Separation-individuation revised: On the interplay of parent-adolescent relatios, identity and emotional adjustment in adolescence. Journal of Adolescence, 28, 89-106.

Meier M., Bureau J.F. (2018), The Development, Psychometric Analyses and Correlates of a Self-Report Measure on Disorganization and Role Reversal. Journal of Child and Family Studies, 27(6), 1805-1817.

Oleszkowicz A., Gwiżdż K. (2019), Formowanie się tożsamości osobistej w okresie stającej się dorosłości, w kontekście poczucia bezpieczeństwa i gotowości do zmian. Polskie Forum Psychologiczne, 24(2), 184-204.

Oleszkowicz A., Senejko A. (2013), Psychologia dorastania. Warszawa: Wydawnictwo Naukowe PWN.

Pasternak A., Schier K. (2014), Life without childhood - parentification of women with ACoA syndrome. Psychiatria Polska, 48(3), 553-562.

Peris T.S., Goecke-Morey M.C., Cummings E.M., Emery R.E. (2008), Marital conflict and suport seeking by parents in adolescence: Empirical suport for the parentification construct. Journal of Family Psychology, 22(3), 633-642.

Pilarska A. (2012), Ja i tożsamość a dobrostan psychiczny. Poznań: Wydawnictwo Naukowe Wydziału Nauk Społecznych UAM.

Pilarska A. (2015), Contextualized self-views and sense of identity. Personality and Individual Differences, $86,326-331$.

Pilarska A. (2016), Wokół pojęcia poczucia tożsamości. Przegląd problemów i propozycja konceptualizacji. Nauka, 2, 123-141.

Pilarska A., Suchańska A. (2015), Procesy tożsamościowe i poczucie tożsamości. Wzajemne powiązania oraz znaczenie dla zdolności do bliskości. Studia Psychologiczne, 53(3), 91-104.

Rowa K., Kerig P.K., Geller J. (2001), The family and anorexia nervosa: Examining parent-child boundary problems. European Eating Disorders Review, 9(2), 97-114.

Sapia-Drewniak E., Żarczyńska-Hyla J. (2017), Parentyfikacja w rodzinie w doświadczeniach młodych dorosłych. Edukacja Dorosłych, 1, 33-42.

Schier K. (2018), Dorosłe dzieci. Psychologiczna problematyka odwrócenia ról w rodzinie. Warszawa: Wydawnictwo Naukowe Scholar.

Stępień E. (1991), Realizacja zadań rozwojowych przez dzieci i młodzież z rodzin z problemem alkoholowym. Alkoholizm i Narkomania, 24, 144-158.

Summers F. (1978), Manual for the measurement of symbiosis in human relationships. Psychological Reports, 43, 663-670.

Titzman P. (2012), Growing up too soon? Parentification among immigrant and native adolescents in Germany. Journal of Youth and Adolescence, 41(7), 880-893.

Toro R.I., Schofield T.J., Calderon-Tena C.O., Farver J.M. (2019), Filial responsibilities, familism, and depressive symptoms among Latino young adults. Emerging Adulthood, 7(5), 370-377.

Van Parys H., Bonnewyn A., Hooghe A., De Mol J., Rober P. (2015), Toward understanding the child's experience in the process of parentification: Young adults' reflections on growing up with a depressed parent. Journal of Marital and Family Therapy, 41(4), 522-536. 
Wells M., Jones R. (2000), Childhood parentification and shame-proness: A preliminary study. American Journal of Family Therapy, 28, 19-27.

Wells M., Glickauf-Hughes C., Jones R. (1999), Codependency: A rass roots construct's relationship to shameproness, low self-esteem, and childhood parentification. American Journal of Family Therapy, 27(1), 63-71.

Żarczyńska-Hyla J., Zdaniuk B., Piechnik-Borusowska J., Karcz-Taranowicz E., Kromolicka B. (2016), Uwarunkowania parentyfikacji doświadczanej w dzieciństwie i okresie dorastania z perspektywy młodych dorosłych. Rocznik Andragogiczny, 23, 199-215. 